\title{
THE MICROSCOPICAL EXAMINATION OF THE DISCHARGE IN ONE HUNDRED CASES OF MIDDLE-EAR SUPPURATION, WITH AN ANALYSIS OF THE RESULTS, HAVING SPECIAL REFERENCE TO THE PRESENCE OF TUBERCLE AND "ACID-FAST" BACILLI. *
}

By WyatT Wingrale, M.D.,

Physician and Pathologist, Central London Throat and Ear Hospital.

THIs investigation was undertaken not with the view of making an exhaustive bacteriological search, but chiefly with the object of testing the value and reliability of microscopical examinations for acid-fast bacilli available under ordinary circumstances.

The sources of the material were for the most part patients who had not previously undergone any special treatment, and although many of them afforded family and personal evidence of tuberculosis, they were not purposely selected for that reason, but were taken in the ordinary course of out- and in-patient practice at the Central London Throat and Ear Hospital, together with a few private cases. Mr. St. George Reid, the bacteriologist, kindly co-operated in verifying the morphological characters of the micro-organisms.

Collecting the Material.-Having experienced the unreliability of scrapings taken from the superficial regions of the auditory meatus, the discharge was always taken from the deepest available part, as near as possible to the diseased area. In some instances the granulations themselves, with the pus and débris, were triturated with a 2 per cent. solution of sodium sulphate, and centrifuged before staining.

\section{Synopsis of Results.}

\begin{tabular}{|c|c|c|c|c|c|c|}
\hline & & & & & & \\
\hline Age-Under 1 & year & $\ldots$ & $\cdots$ & $\cdots$ & $\cdots$ & \\
\hline 2 to $6 \mathrm{~J}$ & jears & $\ldots$ & $\cdots$ & $\ldots$ & $\cdots$ & 6 \\
\hline 7 to 14 & $"$ & $\cdots$ & $\ldots$ & $\ldots$ & $\ldots$ & 21 \\
\hline 15 to 21 & , & $\ldots$ & $\ldots$ & $\ldots$ & $\ldots$ & 29 \\
\hline 22 to 31 & ", & $\ldots$ & $\ldots$ & $\ldots$ & $\cdots$ & 18 \\
\hline 32 to 51 & , & $\ldots$ & $\ldots$ & $\ldots$ & $\ldots$ & 14 \\
\hline 52 to 62 & & $\ldots$ & $\ldots$ & $\cdots$ & $\cdots$ & \\
\hline Sex-Equal is & numl & ber. & & & & \\
\hline History of $P$ & hisis, & family & or $\mathrm{p}$ & sonal & $\cdots$ & 42 \\
\hline Acid-and Alc & hol-fa & st bacil & & $\ldots$ & $\ldots$ & 24 \\
\hline B. T. $(p$ & sump & tive) & $\ldots$ & $\ldots$ & $\cdots$ & 7 \\
\hline Pseu & $\mathrm{T}$. & $\ldots$ & $\cdots$ & $\ldots$ & & \\
\hline
\end{tabular}

Of the 17 B. T., 12 had history of phthisis.

Of the 7 P." B. T., 5 had history of phthisis.

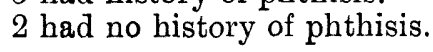

* Communicated to the Otological Society of the United Kingdom, February 2,1903 , in opening a discussion on "Tuberculosis of the Ear, the Nose and the Naso-pharynx." 


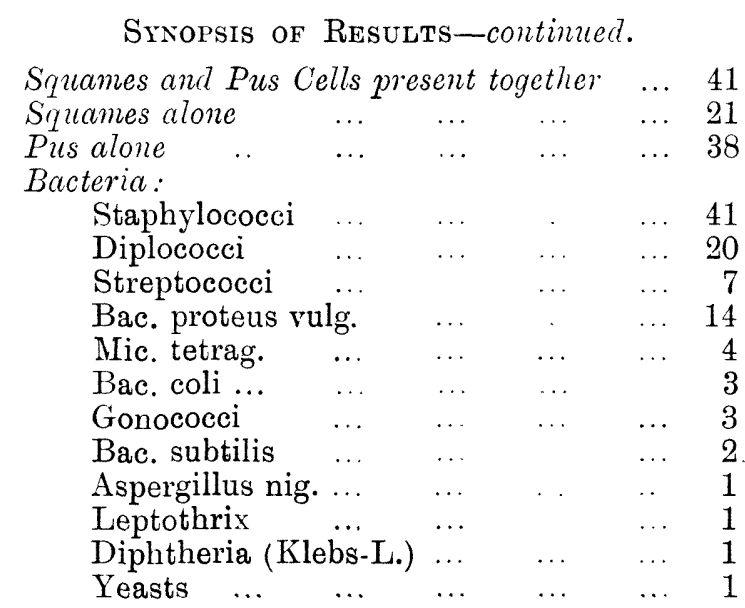

Routine Staining. - The discharge was removed with a small curette, squeezed between sterilized cover-glasses, and fixed by heat. After boiling in carbol fuchsine for three minutes the smear was placed in 25 per cent. sulphuric acid until all colour had disappeared; but if on washing with water the colour reappeared the acid bath was repeated. After further washing in water, if apparently colourless, it was soaked in absolute alcohol for five minutes, counterstained with methylene blue, washed, dried, and mounted in xylol balsam.

Although this process may be carried out while the cover-glass is held by Cornet's forceps, it will be found that the details can be more thoroughly and as quickly performed in a test-tube, using a liberal supply of solutions.

Specimens from the same cases were also stained by Gram's method, which proved more reliable than methylene blue as a general stain. They all resisted the action of 5 per cent. solution of tartaric acid after prolonged soaking.

\section{Synopsis of Table of Results.}

On referring to the table (pp. 128-130) it will be seen that the cases were all suffering with chronic suppuration of the middle ear with the three following exceptions:

No. 50 was one of chronic non-suppurative disease of the middle ear in a patient suffering with pulmonary tuberculosis.

No. 52 was that of an infant ten months old suffering with mastoid abscess and a discharge of four days' duration, under Dr. Jakin's care. The abscess and discharge both contained gonococei. 
No. 76 was also that of an infant twelve months old with a discharge of five days' duration. This also contained gonococci.

It will be seen that in twenty-four cases bacilli which resisted both acid and alcohol were present. Of these, seventeen conformed to the morphological characters of the bacillus of tubercle, and, further, were accompanied in twelve instances with either a personal or family history of tuberculosis. These are described as presumably genuine tubercle bacilli. The remaining seren cases showed bacilli varying in sereral respects (size, shape, etc.) from the orthodox features, although affording the correct staining reactions, and are grouped as Ps'mlu-tulercular, as suggested by Pappenheim. In these also there was a history of tuberculosis in four cases. The number of bacilli present in each smear varied considerably, from twelve in each field to less than a dozen in a whole smear.

We now know that all acid-fast bacilli are not necessarily tubercle, and in considering their significance it may be well to enumerate some of the chief non-tubercular acid-and alcohol-fast bacilli which have been reported.

1. Smegma bacillus. - This is acid-resisting, but is readily heached by alcohol-less so by acid. It is smaller than that of tubercle, and is said to be found only on the male genitals.

2. Leprosy Barillus. - This may be disregarded in the present investigation, owing to its rarity in this country.

3. T'imothy and other Grass Bacilli. - Resist both acid and alcohol, but inoculation experiments have proved negative.

4. Lustgarten's Bacillus of Syphilis. - The identity of this hacillus has not received satisfactory confirmation. It, however, is easily bleached by acid-less so by alcohol.

5. Butter Bacillus. - This is probably identical with a grass lacillus.

6. Bacillus of Pulmonary Gangrene.-This has been described by Pappenheim ${ }^{1}$ as a Pseudo-tubercular bacillus, while Fraenkel ${ }^{2}$ attributes its resistance to acids, to the putrefactive changes being rich in fatty acids, etc.; for when occurring in sweet sputum they give up their stain readily.

7. Lubarsch $^{3}$ also found similarly selective bacilli in : (a) Purulent bronchitis; (b) bronchiectasis; (c) abscess near hipjoint; $(d)$ sebaceous cysts; in all of which cases inoculation results were negative.

8. Folli ${ }^{+}$found acid-fast bacilli in three out of six cases of non-tubercular pulmonary gangrene. He observed that they were 
decolourized after five minutes' soaking in 5 per cent. solution of tartaric acid, while genuine tubercle bacilli required twenty minutes. This reaction I have not been able to confirm, as already mentioned.

In addition to these, there are many others which are referred to in the appendix.

Thus we have evidence that many bacilli exist which may be mistaken for tubercle, and we must not be too ready to accept their identity, whatever their source may be.

This investigation has revealed another possible source of error. In about 60 per cent. of the preparations epithelial squames formed a most striking feature; they retained the fuchsine to a remarkable degree, in spite of prolonged treatment by acid and alcohol. It was noticed that the older the squames the more vividly they retained the fuchsine, the younger ones being paler, whilst the most recent of all being unstained with fuchsine, but readily selecting the methylene blue. This property is probably due to the increase of keratin and fatty substances, the result of degenerative age-changes in the cell, and supports Fraenkel's suggestion that the fuchsine selecting and retaining power of some bacilli is due to the degeneration products and fatty acids of putrefaction.

These cells often break up into small, irregularly-shaped rods and granular clumps, which may readily be mistaken for microorganisms of the acid-fast group.

They are of still further interest in possessing a diagnostic value, since if the smear be taken from the deepest part of the ear they afford strong presumptive evidence of cholesteotoma, especially, too, when, as not unfrequently happens, they are more numerous than pus-cells. They are invariably accompanied with a distinctive sour fœtor-that of decomposing epidermis, probably due to fatty acids and sulphur, in marked contrast to that of bony necrosis, which has more the character of phosphorus.

C'ases of Special Interest.-No. 15 is that of a female with a strong family history of tubercle, four having died from phthisis. In addition to suffering with pulmonary tuberculosis, she is nearly blind with double optic neuritis, which Mr. Treacher Collins attributes to a retrobulbar tubercular lesion. She has suffered with suppurative discharge from both ears for seven years, in which I have found bacilli on each of several examinations. The sputum afforded similar results.

No. 50 was one of chronic non-suppurative middle-ear disease of eight years' duration. There being evidence of some accumulation in the right ear, Dr. Dundas Grant performed paracentesis 
of the membrane, evacuating a few drops of inspissated matter, which contained tubercle bacilli. His sputum afforded abundant evidence of the same bacilli.

Gonococei occurred in three cases, two of which were infants and one was a male aged thirty-nine. The presence of this organism is not without interest, especially during infancy.

In No. 74 tubercle bacilli were found not only in the aural discharge, but also in the pus of the cerebral abscess, operated on by Dr. Dundas Grant. She had a strong family history of phthisis and was much emaciated, but made an excellent recovery.

Conclusions. - This investigation shows that acid- and alcoholfast bacilli are demonstrable in a large proportion of chronic purulent ear discharges.

That in seventeen cases they were presumably tubercle bacilli, in so far that they conformed to the recognised morphological and staining characters and were for the most part associated with reliable clinical evidence of tuberculosis.

That in seven (pseudo-tubercle bacilli) cases, while conforming in a greater or less degree to the staining requirements, they were morphologically unlike tubercle bacilli, yet five of them had either a family or personal history of phthisis.

That success in their demonstration in a great measure depends upon the methods of collecting and staining, together with perseverance in search.

That in the peculiar selective action of the squames in retaining the carbol fuchsine-a property specially attributed to certain bacilli-we have at once a possible source of error in diagnosis and an explanation of the peculiar. affinity of other bacilli for fuchsine. 


\section{TABLE OF RESLLTS.}

Column 1 refers to the nature of the aural disease.

"2 2 gives the duration of the aural symptoms.

"3. The sign + indicates that there was either a family history of tubercle or that there was clinical evidence of such in the patient. independently of the ear.

„ $\quad$ 6. B. T. refers to acid- and alcohol-fast bacilli, presumably tubercular.

P. B. T. represents Pseudo-bac. of tubercle.

B. P. V. refers to Bac. proteus vulgaris.

N.B.-An exhaustive list of the bacteria found is omitted.

, 7 records the organized cells present, in the order of prevalence.

\begin{tabular}{|c|c|c|c|c|c|c|c|c|}
\hline & 1. & 2. & 3. & 4. & 5. & 6. & 7. & \\
\hline & Discase. & $\begin{array}{l}\text { Durre- } \\
\text { tion. }\end{array}$ & $\begin{array}{l}\text { History of } \\
\text { Phthisis. }\end{array}$ & $A y c$ & Ser. & Breterie. & $6.77 s$. & Remurks. \\
\hline 1 & C.S. M. E. & 3 & 0 & 23 & F. & $\begin{array}{l}\text { Diplococci, } \\
\text { staphylo- } \\
\text { cocci. }\end{array}$ & $\begin{array}{l}\text { Pus, few } \\
\text { squames. }\end{array}$ & \\
\hline 2 & $"$ & $1 \mathrm{mo.}$ & 0 & 13 & $\mathrm{M}$. & Streptococci & Pus. & \\
\hline 3 & $"$ & 3 & 0 & 25 & M. & Staph. & $\begin{array}{l}\text { Squames, } \\
\text { pus. }\end{array}$ & \\
\hline 4 & $"$ & 6 & 0 & 13 & $\mathrm{~F}$ & Staph. & Squames. & \\
\hline 5 & $"$ & 21 & 0 & 21 & II. & $\begin{array}{l}\text { B. P. V., } \\
\text { staph. }\end{array}$ & $\begin{array}{l}\text { Squames, } \\
\text { pus. }\end{array}$ & \\
\hline 6 & $"$ & 2 & 0 & 16 & M. ' & B. P. T. & $\begin{array}{l}\text { Squames, } \\
\text { pus. }\end{array}$ & \\
\hline 7 & & 6 & 0 & 24 & F. & None found. & Squames. & \\
\hline 8 & $"$ & 14 & 0 & 17 & $F$ & Dipl. & $\begin{array}{l}\text { Squames, } \\
\text { pus. }\end{array}$ & Cured. \\
\hline 9 & $"$ & 31 & + & 36 & F. & Staph. & Squames. & \\
\hline 10 & $"$ & 3 & + & 14 & F. & $\begin{array}{l}\text { B. T., } \\
\text { B. P. } v .\end{array}$ & $\begin{array}{l}\text { Pus, } \\
\text { squames. }\end{array}$ & \\
\hline 11 & " & 4 & + & 23 & F. & P. B. T. & $\begin{array}{l}\text { Pus, } \\
\text { squames. }\end{array}$ & \\
\hline 12 & $"$ & 6 & 0 & 20 & M. & Staph. & Squames. & \\
\hline 13 & $"$ & 4 & + & 34 & F. & Staph. & $\begin{array}{l}\text { Pus, } \\
\text { squames. }\end{array}$ & \\
\hline 14 & " & 4 & + & 17 & F. & $\begin{array}{l}\text { Staph., } \\
\text { P. B. T. }\end{array}$ & Squames. & \\
\hline 15 & " & 5 & + & 24 & F. & $\begin{array}{l}\text { Staph., B.T., } \\
\text { B. P. V. }\end{array}$ & $\begin{array}{l}\text { Pus, } \\
\text { scluames. }\end{array}$ & Optic neuritis. \\
\hline 16 & " & - & 0 & - & M. & $\begin{array}{l}\text { Staph., } \\
\text { B. T. }\end{array}$ & $\begin{array}{l}\text { Squames, } \\
\text { pus. }\end{array}$ & \\
\hline $\begin{array}{l}17 \\
18\end{array}$ & , & 15 & $\begin{array}{l}+ \\
0\end{array}$ & 38 & $\begin{array}{l}\text { F. } \\
\text { YI. }\end{array}$ & Staph. & isquames. & \\
\hline 19 & $"$ & 15 & + & 18 & $\begin{array}{l}\text { M. } \\
\text { F. }\end{array}$ & $\begin{array}{l}\text { P. B. T. } \\
\text { P. B. T. }\end{array}$ & $\begin{array}{l}\text { Squames. } \\
\text { Squames. }\end{array}$ & \\
\hline 20 & ", & 9 & 0 & 38 & i. & B. T. & Squames. & \\
\hline 21 & " & 3 & + & $\bar{z}$ & - & P. B. T. & Pus. & \\
\hline 22 & $"$ & 7 & + & 15 & F. & B. T., dipl. & $\begin{array}{l}\text { Pus, } \\
\text { sffuames. }\end{array}$ & \\
\hline $\begin{array}{l}23 \\
24\end{array}$ & $"$ & $\begin{array}{l}4 \\
7\end{array}$ & + & 19 & F. & Dipl. & Pus. & \\
\hline 24 & $"$ & 7 & 0 & 11 & M. & $\begin{array}{l}\text { Staph., lep- } \\
\text { tothrix. }\end{array}$ & Sifuames. & \\
\hline 25 & , & 4 & 0 & 17 & F. & Dipl., staph. & $\begin{array}{l}\text { Pus, } \\
\text { squames. }\end{array}$ & \\
\hline $\begin{array}{l}26 \\
27\end{array}$ & $"$ & 18 & 0 & 22 & M. & Iipl. & Squames. & \\
\hline 27 & $"$ & 20 & 0 & 34 & M. & $\begin{array}{l}\text { Staph., } \\
\text { yeasts. }\end{array}$ & Squames. & \\
\hline 28 & $"$ & 5 & + & 22 & F. & B. T. & Pus. & Cerebral \\
\hline 30 & $"$ & 4 & - & 19 & MI. & Strept. bac. & Pus. & [abscess. \\
\hline $\begin{array}{l}30 \\
31\end{array}$ & $"$ & $\begin{array}{l}17 \\
12\end{array}$ & $\begin{array}{l}+ \\
0\end{array}$ & $\begin{array}{l}22 \\
19\end{array}$ & $\mathrm{MI}$ & $\begin{array}{l}\text { Strept. } \\
\text { Dipl., B. T. }\end{array}$ & $\begin{array}{l}\text { Pus. } \\
\text { Pus. }\end{array}$ & \\
\hline
\end{tabular}



